\title{
COMMERCIAL-LAW REASONS (OTHER THAN TAX) FOR SETTING UP A HEADQUARTER COMPANY: A SOUTH AFRICAN OBSERVATION
}

\author{
Thabo Legwaila \\ Bluris LLB LLM PGDip Tax Law LLM LLD \\ Extraordinary Lecturer, Mercantile Law \\ University of Pretoria
}

\section{SUMMARY}

A headquarter company is a company within a group of companies which supervises and co-ordinates the administrative activities of the group. Headquarter companies are formed for various tax- and non-tax-related reasons depending on the particular needs of the group in which the headquarter company is formed. In the setting up a headquarter-company consideration is given to various key determinants such as political and investment climate, corporate laws and treasury considerations. Tax reasons include deferring tax on income and capital gains, maximizing credit for foreign taxes and reducing withholding taxes. However, when the decision is taken to interpose a headquarter company between the investor country and the operating subsidiaries' country, the real economic purposes and benefits are usually non-tax in nature. These include the ability to raise external finance, circumventing the application of exchange controls, protection of assets as well as group reorganization and structural consolidation.

\section{INTRODUCTION}

One of the methods in which a country could be used to access investment into a region is by investors centralizing finances, co-ordination and administration of their investments in that country. This could be achieved by the setting up of a headquarter company. ${ }^{1}$ A headquarter company is generally set up with the purpose of achieving economic and structural purposes for the company group.

The South African National Treasury announced in the 2010 Budget review, ${ }^{2}$ and reiterated in the 2011 Budget Review ${ }^{3}$ that it intends to promote South Africa as a gateway to investment into Africa. In pursuance of this goal, the National Treasury examined the South African corporate and business framework as well as exchange-control and corporate-tax laws, to determine if the corporate, business, legal and tax environment could stifle

See definition of headquarter company in par 2 below.

National Treasury Budget Review (2010) 78-79.

National Treasury Budget Review (2011) 73. 
the ability of South Africa to serve as a base through which investors could access investment opportunities into Africa. ${ }^{4}$ Furthermore legislation has been amended in order to remove any identified impediments to attracting headquarter companies to South Africa. ${ }^{5}$ The 2011 legislative amendments to the corporate tax laws, as well as the recent exchange-control amendments, contained relaxation measures to the regulations that would enable South Africa to host headquarter companies. Some countries such as the Netherlands $^{6}$ and Mauritius ${ }^{7}$ have prioritized investment in the form of holding companies for over a decade and have been successful in designing tax systems that attract holding companies. Other countries, such as Belgium, Ireland and the United Kingdom have not been as successful despite amending their tax systems to attract holding companies. ${ }^{8}$ More often than not, the focus is on the tax attributes of a country totally oblivious of the fact that the infrastructure that makes a holding company efficient consists of the legal and economic attributes of the country.

Given this increased appetite to create enabling environments for holding companies, it has become more important than ever to understand not only what is a headquarter company, but also why an investor would prefer to include such a company within the investment structure. They are set up to achieve both tax and non-tax objectives. As to which objectives drive the decision to set up a headquarter company depends on the company-group needs.

This article analyses the economic and structural or organizational purposes for which investors incorporate and use headquarter companies within their company-group structures. The article does not discuss taxrelated objectives of a headquarter company.

4 See National Treasury Budget Review 78-79. See also Lermer "2010 Budget Attracts SA Based Headquarter Companies" Moneyweb http://www.moneyweb.co.za/mw/view/mw/en/ page302588? oid=347864\&sn=2009\%20Detail (accessed 2012-04-01); and Legwaila "The Tax Treatment of Holding Companies in Mauritius: Lessons for South Africa" 201123 SA Merc LJ 1.

5 See Taxation Laws Amendment Act 7 of 2010; and s 9 I and 10B of the Income Tax Act 58 of 1962 (hereinafter "the Income Tax Act").

6 Boon "The Holding Regime in the Netherlands" 1992 18(4) The International Tax Journal 48-73; Bayliff and Teves "Using the Netherlands as an Operational Base" 19854 International Financial LR 31-35; Turkenburg "The Netherlands Woos Foreign Investors" 1993 International Tax Review 31-32; Boudewijn "Using a Dutch Intermediary Company to Help Manage and Control an Organization's Worldwide Tax Liabilities" 1994 The International Tax Journal http://proquest.umi.com/pqdweb?did=7645136\&Fmt=2\&clientld= 27625\&RQT=309\&VName=PQD (accessed 2011-11-17); Brood "Dutch Credit for Foreign Withholding 19956 International Tax Review 20-22; De Jong "The Netherlands" 1995 International Tax Review 30-38; Jenner and De Koning "Dutch Law Offers Mixed Blessings 19967 International Tax Review 21-24; and Van der Donk "Dutch Boost for Multinationals" 19967 International Tax Review 31-33.

7 Mauritius: Country and Foreign Investment Regime http://www.lowtax.net/lowtax/html/ jmucfir.html (accessed 2010-05-13). About Mauritius ... Our World Tax Haven Director http://www.ascotadvisory.com/Incorporations Directory/Mauritius.html (accessed 2012-0513); Mauritius Offshore Company Formation. Which Type is Best for You http://www.content4reprint.com/finance/financial-planning/mauritius-offshore-company-for mation.-which-type-is-best-for-you.htm (accessed 2012-05-15); and Legwaila 201123 SA Merc LJ 1-15.

8 See Legwaila "Tax Impediments to Holding Company Structures in Belgium, Ireland and the United Kingdom: Caution for South Africa" 2011128 SALJ 533-560. 


\section{WHAT IS A HEADQUARTER COMPANY?}

A headquarter company is "a company within a multinational group of companies which supervises and co-ordinates the administrative activities of the group's subsidiaries without engaging in the control, strategy or management of the group". " Generally the headquarter company is interposed between the ultimate holding company and the operating subsidiaries of the group. It is a subsidiary of an ultimate holding company in a group and a holding company of operating companies.

Headquarter companies are often formed where multinational groups of companies have significant economic interests in a region which is distant from its head office to oversee and co-ordinate the group's business interests in a particular region. For that reason, the headquarter company is generally incorporated in the country or region in which the subsidiaries operate as opposed to the country of residence of the ultimate holding company or the latter's shareholders.

"Such centres will usually provide the full range of administrative and management functions associated with a head office; for example, treasury and tax management, internal audit, public relations, market research and marketing, insurance and accounting." ${ }^{11}$ It is, therefore, not infrequent that $a$ group of companies would have multiple international headquarters each serving group companies in contiguous countries within a particular region.

The choice of the location of a headquarter company is flexible and geared towards achieving the specific goals for which it is needed (largely dependent on the purposes and the tax system applicable).

For South African purposes a headquarter company is a company that satisfies the following criteria: ${ }^{12}$

- for the duration of the year of assessment and all previous years of assessment, each shareholder of the company must hold at least $10 \%$ of the equity shares and voting rights in the headquarter company;

- at the end of the year of assessment and all previous years of assessment, $80 \%$ or more of the cost of the total assets of the headquarter company should be attributable to:

$\circ$ an interest in equity shares in;

$\circ$ an amount loaned or advanced to; or

o intellectual property licensed by the headquarter company to;

any foreign company in which the headquarter company held at least $10 \%$ of the equity shares and voting rights;

- if the gross income of the company exceeds R5 million, $50 \%$ or more of the gross income must consist of amounts in the form of rentals,

Olivier and Honiball International Tax, A South African Perspective (2008) 575.

10 See http://www.freemontgroup.com/eng/jurisdicties/cyprus.php (accessed 2012-03-10).

1 Ogley Principles of International Tax: A Multinational Perspective (1993) 137.

2 S 1 definition of "headquarter company" read with s 9 I of the Income Tax Act. 
dividends, interest, royalty or service fees paid by the foreign company; and proceeds from the disposal of any interest in equity shares in a foreign company or any intellectual property licensed by the headquarter company to the foreign company.

\section{GENERAL REASONS FOR SETTING UP A HEADQUARTER COMPANY}

Generally speaking, setting up and using a headquarter company are expensive. As tax laws may change one would generally not set up a headquarter company with the sole purpose of taking advantage of a specific tax regime. As McGonagle states, "[t]he location of choice for a [headquarter company] will depend both on tax and non-tax considerations; it should offer something more than merely a low rate of tax". ${ }^{13}$

The financial costs of maintaining an international group structure can affect the profitability of the group severely. In most instances an optimized group structure involves multiple tiers of holding companies resident in one or more jurisdictions to address economic and structural objectives as well as various tax objectives. ${ }^{14}$ In the setting up of such a structure consideration is given to various key determinants such as:

- Political and investment climate,

- company or corporate law, the rule of law and the availability of reputable law, accounting and audit firms; ${ }^{15}$

- treasury considerations, including monetary controls, foreign exchange and currency exposure;

- administrative ease and the availability of reputable service firms;

- existing operational substance; and

- infrastructure and cost factors. ${ }^{16}$

When the decision is taken to interpose a headquarter company between the investor country and the operating subsidiaries' country, the real economic purposes and benefits are usually non-tax in nature. To a very

13 McGonagle "Ireland Aims to Attract Holding Companies" 2004 International Financial LR http://proquest.umi.com/pqdweb?did $=783749051 \& \mathrm{Fmt}=3 \&$ clientld $=27625 \& \mathrm{RQT}=309 \& \mathrm{VNa}$ me=PQD (accessed 2012-03-12).

14 Finnerty Introduction - Holding Companies http://online2.ibfd.org/collections/hold/html/hold introduction.html (accessed 2012-03-01); and Legwaila "Intermediary Holding Companies and Group Taxation" 2010 De Jure 308-327.

$15 \mathrm{Eg}$, according to Shelton, one of the reasons why the Danish holding-company regime was not successful in the late 1990s although the Danish infrastructure was extremely welldeveloped and functions well, was that one will not find many accountants, lawyers or bankers as familiar with the formation and administration of Danish intermediary holding companies as in a number of other jurisdictions (Shelton "Denmark Squares up for Holding Battle" December 1998 / January 1999 International Tax Review http://www.internationaltax review.com $/$ Page $=10 \& P U B I D=35 \& I S S=12655 \& S I D=468670 \& S M=\& S$ earch $S t r=\% 22$ interm ediary\%20holding\%20company\%22 (accessed 2012-01-07).

16 See Finnerty Introduction - Holding Companies par 1.3. 
large extent they are based on the legal infrastructure of the particular jurisdiction. The most common benefits are the following: ${ }^{17}$

1. Supervision and co-ordination of administrative services;

2. group finance facilities;

3. listing;

4. exchange controls;

5. holding, with a combination of non-holdng reasons;

6. asset protection; and

7. structural and group reorganisation.

What follows is an analysis of each of these non-tax reasons for setting up and operating a headquarter company. It is noted that there are instances where headquarter companies are formed primarily for tax reasons. ${ }^{18} \mathrm{An}$ indepth analysis of the reasons for formation is beyond the scope of this article.

\section{Supervision and co-ordination of administrative services}

Headquarter companies are often formed by multinational groups to oversee and co-ordinate the group's business interests in a particular region. They provide the full range of administrative functions associated with a head office, mainly treasury and tax management. In this way, the headquarter company acts as the head of a regional or functional group or subgroup of subsidiaries. $^{19}$

\section{Group finance facilities}

Financing a company or business operations generally takes the form of equity or debt. ${ }^{20}$ Equity instruments generally represent ownership interests

17 See Rohatgi Basic International Taxation (2002) 238. See also Olivier and Honiball International Tax, A South African Perspective 299.

18 See Bergmann, Hirschler, Rödler and Kornberger "Tax Treatment of Holding Companies in Austria" 2004 Bulletin for International Fiscal Documentation 418.

19 This function is usually coupled with the function of reducing the overall dividend withholding tax costs or converting capital gains into dividends for parent companies http://www.freemontgroup.com/eng/jurisdicties/cyprus.php (accessed 2012-02-26). See also Lambooij and Peelen "The Netherlands Holding Company - Past and Present" 2006 Bulletin for International Taxation par 2.3.1.

20 Both of these types of financing can take different and varied forms. Each of these two categories presents a wide variety of rights, privileges and limitations that may be established by the issuing company. Debt financing refers to borrowing money to finance a business undertaking. The money is to be repaid over a period of time, usually with interest. The lender does not gain an ownership interest in the business and the obligations are limited to repaying the loan. Equity financing on the other hand describes an exchange of money for a share of business ownership. 
entitled to dividend payments, when declared, but with no specific right to a return on capital. An issuer of an equity instrument generally does not receive a deduction for dividends paid and the holder generally includes such dividends in the calculation of taxable income. ${ }^{21}$

Equity financing may be through an issue of shares either to the public or to the holding company and/or specific persons, such as current shareholders. ${ }^{22}$ As Rohatgi states

"[t]he shares could be ordinary or preferred shares, redeemable or convertible preference shares, participating preference shares or deferred shares. The shares may be issued either at par or no-par value. They may also have unequal rights on voting control, distribution of assets or management decisions."

Save for certain exceptions which are limited in their scope, debt instruments generally represent fixed obligations to repay a specific amount at a specified date in the future. This often coincides with an obligation to pay interest on the amount of the debt. However, there are debt instruments that are issued interest-free due to, inter alia, the relationship between the issuer and the holder. The issuer of a debt instrument may receive a deduction for accrued interest and the holder generally includes interest in taxable income, subject to certain limitations. ${ }^{24}$

In respect of debt instruments the funds may be borrowed in the jurisdiction of the headquarter company (hereinafter referred to as "the host country"), the investor's country of residence (hereinafter referred to as "the home country") or even a third country. In this regard Rohatgi states the following:

"The interest may be payable at regular intervals or on maturity. Again, the interest may be fixed or variable or dependent on profits under a participating loan. The loan may be unsecured, or guaranteed by the [holding] company directly or under a back-to-back arrangement. They may be denominated in the local currency of the borrower or a foreign currency. The borrower is usually obliged to comply with certain loan covenants under the agreement."

Another form of financing is a combination of debt and equity. Actually, most companies are financed by a combination of debt and equity. This combination is generally dictated by economic and commercial considerations. $^{26}$

For a further discussion on the distinctions between debt and equity, see Financing Basics: Debt vs Equity http://www.toolkit.com/small_business_guide/sbg.aspx?hid=P10 2000 (accessed 2011-03-10).

21 Financing Basics: Debt vs Equity http://www.toolkit.com/small_business_guide/sbg .aspx?nid=P10_2000 (accessed 2012-03-10).

22 Rohatgi Basic International Taxation 456. For further reading on financing aspects, see Lyon Taxation, Information Asymmetries, and the Financing Choice of the Firm in Fiscal Incentives for Investment and Innovation (1995) Chapter 1.

23 Rohatgi Basic International Taxation 456.

24 See Debt and Equity Financing http://www.lordalex.org/financialinfo/debt/Debt_and_ Equity_Financing.html (accessed 10 March 2012).

25 Rohatgi Basic International Taxation 456.

26 Rohatgi Basic International Taxation 457. 
Financing can also take the form of instruments that combine both debt and equity. These are called hybrid financing instruments. These instruments combine the flexibility and repayability of debt with the advantages of equity. They include convertible loans, jouissance rights, ${ }^{27}$ option loans, transferable bonds, subordinated loans, profit participating loans, etc, with varying elements of equity and debt. Generally, hybrids are capable of being treated as debt in one country and as equity in another, as well as where the tax law and commercial law of a country characterize the instruments differently. This characteristic enables hybrid instruments to be used to exploit the divergence in the application of tax laws of different jurisdictions either to avoid tax or to claim double benefits. ${ }^{28}$

For tax purposes, from the viewpoint of an investor debt is preferable to equity. Most tax regimes allow a deduction of the cost of financing a debt, i.e. the interest and other finance charges. ${ }^{29}$ Thus, part of the expenditure of the income-producing undertaking can be deducted from the income of the undertaking. There is no such offsetting deduction in relation to equity. As a result the decision to use debt would generally be based on tax reasons. However, the circumstances under which the debt financing is obtained are not tax in nature. The most common tax benefits of using debt are as follows: ${ }^{30}$

- The borrower can reduce its tax by financing through debt, as interest is paid from pre-tax profits as opposed to dividends that are paid from aftertax profits.

- A loan may be obtained in any currency to minimize foreign exchange risks; generally, interest does not suffer from economic double taxation ${ }^{32}$ in the hands of the borrower and the lender.

- And it may be possible for different persons to claim a deduction for the interest costs if the holding company borrows at home to invest in a

27 Jouissance rights are participation certificates that provide security for creditors' claims. These rights are usually reserved for shareholders who are also creditors in the company. They would, eg, carry rights of participation in profits. Participation certificates do not give the bearer any voting rights. They are recorded as supplementary capital under certain circumstances.

28 Rohatgi Basic International Taxation 562 states: "The tax benefits on hybrid instruments arise both from the classification conflicts and the timing differences on income or expense recognition. These advantages are often the result of the tax-rate differences and the timing of the tax due on various payments such as dividends, interest, capital gains or even capital duties."

29 See Organisation for Economic Co-operation and Development, Fundamental Reform of Corporate Income Tax No 16 (2007) 59.

30 Rohatgi Basic International Taxation 457.

31 This is subject to the application of thin capitalization rules.

32 Economic double taxation means the inclusion, by more than one state's tax administration, of the same income in the tax base when the income is in the hands of different taxpayers. This is contrasted with juridical double taxation, which refers to the imposition of income taxes in two (or more) states on the same taxpayer in respect of the same income. See Organisation for Economic Co-operation and Development What is a Tax Convention Double Taxation - Juridical and Economic available on http://www.oecd.org/document /15/0,3343,en_2649_33753_36156239_1_1_1_1,00.html (accessed 2012-03-10). 
foreign subsidiary in a tax haven, which then grants a loan to a sister subsidiary in the host country.

As a result, tax advisors, bankers and lawyers devote significant time and effort to arbitraging the tax, particularly aiming to obtain some tax deduction with some credit from the rating agencies. ${ }^{33}$ This begs the question: what are the commercial and other reasons for locating a company in the host country and not the home country? The most common reasons are country risk, currency risk and usage of group assets. ${ }^{34}$

\section{Country risk}

Owing to the political, social and economic status of a country, a country may be seen to be a higher risk in terms of lending money to residents of that country. This may also be due to the legal system that fails to enforce the rule of law effectively. In such a case it becomes prudent for a group to locate its financial hub outside the home country, in a country with a higher regard of the rule of law. This is in light of the fact that the bulk of the functions of a headquarter company is to oversee the group's business interests in domestic and/or foreign companies. Such transactions require certainty of the legal provisions and enforceability of the obligations arising from the contractual relationship.

The South African legal system provides for robust legal enforcement through the use of various legal instruments of enforcement. ${ }^{35}$ Furthermore, the South African constitution provides for a robust entrenchment of rights against property deprivation. In terms of section 25 , "[n]o one may be deprived of property except in terms of law of general application, and no law may permit arbitrary deprivation of property". ${ }^{36}$ Besides the direct property-rights protection granted by the constitution and the common law, the constitution confers several rights of particular significance to administrative law. These include a right to have disputes settled by a court or other independent forum, ${ }^{37}$ a right of access to information held by government ${ }^{38}$ and a wide standing to enforce constitutional rights ${ }^{39}$. Heralded as one of the most elaborative constitutions in the world, the South African constitution acts as a source of security of property held in South

33 See Hammer "How Should a Corporation Strategically Review its Capital Markets and Financial Activities in the United States?" 200810 Derivatives and Financial Instruments 10.

34 See Olivier and Honiball International Tax, A South African Perspective 298-299.

35 On the content, application and use of South African legal remedies on property rights, to wit, rei vindicatio and rei negatoria see Van Der Walt and Pienaar Introduction to the Law of Property (2002) 166 and 173 respectively. For delictual remedies see Van der Walt and Pienaar Introduction to the Law of Property 175; see also Olivier, Pienaar and Van der Walt Law of Property (1992) on protection of ownership 126, remedies 127, enrichment action 138 and termination 140.

36 S 25(1) of the Constitution of the Republic of South Africa, 1996 (hereinafter "the Constitution"); and Chaskalson and Fick "Constitutional Law" 2006 Annual Survey of South African Law 1-47.)

$37 \mathrm{~S} 34$ of the Constitution.

$38 \mathrm{~S} 32$ of the Constitution.

39 S 38 of the Constitution; see also Hoexter The New Constitutional and Administrative Law Vol 2 (2002) 5. 
Africa, and hence enhancing the suitability of South Africa as an adequate headquarter company jurisdiction. ${ }^{40}$

\section{Currency risk}

The differences in the currencies of the home country and the jurisdiction where the funding is sought may also be a hurdle to the financing of a company for a group. Financiers are generally reluctant to provide foreign borrowings or foreign currency borrowings due to the risk of repayment. ${ }^{4}$ The financial burden increases when the debtor's currency depreciates against the currency in which the debt is denominated.

This risk is reduced if the borrowed funds are denominated in the same currency as the income flows that service the use of funds. This makes it preferable for companies to maximize borrowings within their country of residence. ${ }^{42}$ The creditors' preference to denominate debt in their business currency results in most groups managing such risk by locating a headquarter company in a favourable jurisdiction for finance purposes.

It needs to be noted that where funding is sought in more than one country the headquarter company could be located in a central location suitable for all, or most, countries from which the finance is obtained. Alternatively a group may incorporate numerous headquarter companies in numerous countries or regions to serve subgroups in the group structure.

The South African Rand is ranked amongst the currencies with the least currency risk. Its rating is tantamount to the ranking of currencies of countries such as Mexico and Thailand and often ranked better than the Euro and the Pound as well as currencies of countries such as Russia, Australia, Brazil, Egypt, Indonesia and Turkey. ${ }^{43}$

\section{Usage of group assets}

Where a company requires finance by way of a loan, its assets may often serve as collateral for that loan. The provision of collateral often poses problems where the company's position is precarious and such company fails to provide the financier with enough security for the loan. However, the usage of the headquarter company to acquire financing for such a company may yield quicker success as the headquarter company may be able to utilize the assets of all its subsidiaries or investments to provide security for

40 See Beehive The South African Constitution http://southafrica.thebeehive.org/content/ 600/1487 (accessed 2012-06-15); Southern African Regional Poverty Network South Africa in Africa: Promoting Constitutionalism in Southern Africa 1994-2004 http://southafrica.the beehive.org/content/600/1487 (accessed 2012-06-15).

41 International Monetary Fund Foreign Currency Borrowing More Risky for Eastern Europe http://www.imf.org/external/pubs/ft/survey/so/2008/car102808a.htm (accessed 2012-05-21); Daily Reckoning Borrowing and Paying Back in a Foreign Currency http://www.daily reckoning.com.au/borrowing-paying-foreign-currency/2009/11/18/ (accessed 2012-05-21).

42 Daily Reckoning Borrowing and Paying Back in a Foreign Currency http://www.daily reckoning.com.au/borrowing-paying-foreign-currency/2009/11/18/ (accessed 2012-05-21).

43 Sovereign Risk and Currency Risk Ratings by Country http://seekingalpha.com/article/ 248600-sovereign-risk-and-currency-risk-ratings-by-country (accessed 2012-06-10). 
the loans. In this regard the South African legal system provides for various forms of security such as a pledge, mortgage, guarantee or suretyship. Thus the headquarter company resident in South Africa could place all its consolidated group assets as security for debt to allow the group or members of the group to finance their operations.

\section{$33 \quad$ Listing}

Where the group intends to list on a stock exchange, the headquarter company is often used as a top-listed holding company the shares of which are or will be traded on a stock or securities exchange. The purposes of listing are largely dependent on the need for the company to raise external finance. Thus, the need for listing arises more when the headquarter company is set mainly or partly to provide the group with finance facilities as was seen above. ${ }^{44}$

Listing on an exchange has several advantages. The main advantages are: ${ }^{45}$ firstly, it is often cheaper to raise equity capital rather than to rely on debt finance to fund the expansion of a company's business, and a listed company is more able to raise such equity capital. Secondly, a listing better enables the company to obtain other forms of finance, such as bank loans. A listing enhances the status of the company. Prospective providers of finance may take some comfort from the fact that its financial information and actions will be subject to the rules and regulations of the stock exchange and public scrutiny. Thirdly, a listing enables a company to use its shares to fund acquisitions, as sellers are more likely to accept listed shares as consideration. ${ }^{46}$

In South Africa, a company is able to list its shares or depository receipts on an exchange as defined in the Securities Services $\mathrm{Act}^{47}$ and licensed in terms of that Act. ${ }^{48}$ The main listing stock exchange is the Johannesburg Stock Exchange Limited (hereinafter "JSE Limited"). Furthermore, the AltX, the alternative exchange, is a division of the JSE Limited. It is a parallel market focused on good quality, small and medium sized high-growth companies. AltX provides smaller companies not yet able to list on the JSE Main Board with a clear growth path and access to capital. ${ }^{49}$ This ability to list on two separate exchanges enhances South Africa's suitability to attract headquarter companies.

\section{Exchange controls}

Exchange controls are used to regulate the influx and outflow of funds and investments into and from countries. Typically these controls permit and restrict certain financial movements in and out of the country. Transactions

\footnotetext{
See par 32 above.

See http://www.jse.co.za/docs/listings/guidelines.pdf (accessed 2012-04-01).

Ibid.

S 1 of the Securities Services Act 36 of 2004

48 The licensing provisions are contained in s 10 of Act 36 of 2004.

49 See http://www.jse.co.za/How-To-List/AltX.aspx (accessed 2012-06-11).
} 
that are affected by exchange controls are subject to either prior government approvals or post-transaction reporting of income or capital flows.

Ordinarily, exchange controls may result in forced repatriation of profits where a resident invests in a country outside the exchange-control free area (where there is one). ${ }^{51}$ Exchange controls may also result in the trapping of profits where a non-resident invests in a country which has exchange controls. As a result, headquarter companies are sometimes incorporated outside an exchange-control country in order to facilitate reinvestment and prevent forced repatriation of profits or the trapping of profits in an exchange-control country. ${ }^{52}$

Exchange controls are also used in some countries as anti-tax avoidance measures on cross-border transactions. However, due to their impact on international trade and commerce, exchange controls are not suitable antiavoidance measures for tax purposes. ${ }^{53}$

South Africa imposes exchange controls on currency and capital movements. The South African government's general policy approach to exchange control is one of prohibition to deal in foreign exchange except with the permission of and on the conditions set by the South African Reserve Bank (hereinafter "SARB"). As the SARB states, "[t]he economic policy underlying exchange control is, however, not totally prohibitive, since such approach would not be conducive to conduct of international trade and payments".

In terms of the Exchange Control Circular No 2/2011 issued by the SARB ${ }^{55}$ headquarter companies are, however, granted special treatment. In terms of the Circular, subject to registration for approval with the Financial Surveillance Department of SARB, headquarter companies will be treated, for exchange-control purposes, as non-resident companies other than for their reporting obligations. Reporting of the extent of the offshore investments will be required for statistical purposes which must, inter alia, include the source of funds, new or existing funds, destination, loan funds from local sources, etcetera. As a non-resident, a registered headquarter company may therefore raise and deploy capital offshore without restriction. The headquarter company can freely borrow from abroad and such funds may be deployed locally or offshore. Transactions by South African entities with headquarter companies will be viewed as transactions with non-

See Rohatgi Basic International Taxation 432

1 Exchange-control free areas are areas within which no exchange-control restrictions are in place on trade between residents of different countries. This often occurs as a result of proximity of the countries, usage of the same currency and the trade relationships (including the frequency of trade transactions) between countries.

52 See Olivier and Honiball International Tax, A South African Perspective 533.

53 Rohatgi Basic International Taxation 432.

54 The South African Reserve Bank Exchange Control Manual Part E http://www.resbank. co.za/pages/default.aspx (accessed 2012-05-15).

55 See http://www.resbank.co.za/fastsearch/Pages/Results.aspx?k=headquarter\%20Exchange \%20Control\%20Circular\%20No.\%202\%2F2011 (accessed 2012-05-15). 
residents. These transactions will be regarded as occurring outside South Africa. $^{56}$

\section{Asset protection}

An essential aspect of entering into a trade or conducting a business is earning a profit. Such profits either increase the assets of the business or are passed on to the investor by way of dividends. In both cases these profits increase the net worth of the investor. It is therefore important that the assets of the business, which are ultimately the assets of the investor, are protected and safe.

Depending on the nature of the business undertaking, the nature of the protection of the assets of the undertaking would differ. The costs of insuring the assets may also differ. Irrespective of the nature of the assets, attendant upon conducting business of any nature is a responsibility to ensure that the assets of a business are secure.

\section{What is an "asset"?}

In the context of the current discussion "asset" is used in a wide sense. It is used as property of whatever nature, whether movable or immovable, including tangible and intangible assets, corporeal or incorporeal, including rights or interests of whatever nature to or in such property. ${ }^{5}$

\section{What are the dangers?}

The dangers to asset security depend on the nature of the business. While land claims, for example, may be a threat to a mining company in many countries including South Africa, they may not be so for a headquarter company. A headquarter company primarily holds investments in its subsidiaries. The main threat to such assets is expropriation by the government of the country where the assets are located. This may not necessarily be the same country as the country in which the headquarter company is located.

Expropriations generally happen as a result of changes in government policy. As a result countries that are politically unstable pose a bigger security threat to the assets of a headquarter company. Where investors are located in such a politically unstable country, the insecurity might necessitate a change of location to secure the assets. Thus, just as the political stability of a country encourages foreign direct investment, political instability drives investment away. ${ }^{58}$

56 See http://www.ens.co.za/news/news_article.asp?ilD=183\&iType=4 (accessed 2012-0612).

57 See Badenhorst, Pienaar and Mostert Silberberg and Schoeman's Law of Property (2003) 1. This wide definition is based on the nature of interests that a business undertaking may give to the investor. This is based on the definition of "asset" in paragraph 1 of the Eighth Schedule to the Income Tax Act 58 of 1962.

58 Expropriation loss is treated as a tax loss in some countries and is not taken into account in other countries. Also, insurance companies will generally exclude expropriation when determining the total risk to be insured. 
A further threat to the viability of a headquarter company could be brought by business regulations. Regulations could increase the costs of conducting business, for example by requiring high and frequent fees for business licences and requiring companies to contribute a certain percentage of their proceeds or income to social development. Overregulation that is complemented by tough non-compliance penalties increases this level of threat to the economic profitability of the headquarter company and the group as a whole.

As a result of these dangers, a feasible business decision is to locate a headquarter company in a country where the risks are less. This often entails the relocation of the financial hub of the group from a country with high risk-levels into a less risky country. In this way the assets of the group would escape the risk by the formation of the headquarter company in a different country. In this regard, the same protection granted by South Africa as discussed in relation to country risk above applies.

\section{Group reorganization and structural consolidation}

Reorganization broadly refers to a transaction (or transactions) that effects significant changes in the legal or economic structure of companies. These take the form of mergers, divisions, asset acquisitions, share acquisitions and recapitalizations. ${ }^{6}$ In a consolidation, two or more companies transfer their assets and liabilities to a single newly established company. Investors often need to reorganize or consolidate their investment structures in order to inter alia maximize profits, access new markets and products, avoid risks and/or centralize their capital. ${ }^{6}$

The company laws of some countries allow structural consolidations and group reorganizations more readily. Where such consolidation or reorganization is required for economic purposes, directing the consolidation or reorganization to a jurisdiction with flexible company laws is inevitable. ${ }^{62}$ Thus the prohibition or difficulties with consolidations and reorganizations do not necessarily come only from the fiscal side. Even then, certain reorganizations are taxable while others are not. Income-tax systems generally treat reorganizations in which the transferor company disappears as a taxable reorganization or consolidation. ${ }^{63}$ Headquarter companies are located in jurisdictions where reorganization would attract the least regulatory and tax consequences.

59 See par 32 1. See further on asset protection Andrews and Ellmann The Post-Apartheid Constitutions - Perspectives on South Africa's Basic Law (2001); also see Currie and De Waal The New Constitutional and Administrative Law (2001) on property clause 388, meaning of property 388, deprivation and expropriation 392, due process 393 and compensation 396.

60 Vanistendael "Taxation of Corporate Reorganizations" in Thuronyi (ed) Tax Law Design and Drafting, International Monetary Fund (1998) 908.

61 Ibid.

62 See Olivier and Honiball International Tax, A South African Perspective 299; and Rohatgi Basic International Taxation 238.

63 Vanistendael in Thuronyi (ed) Tax Law Design and Drafting 908. 
The South African law readily allows companies to restructure in the form of a amalgamation or merger. ${ }^{64}$ In terms of Chapter 5 of the Companies $\mathrm{Act}^{65}$ titled "Fundamental transactions, take-overs and offers" various administrative requirements should be satisfied. These include the passing of resolutions by the companies amalgamating or merging, ${ }^{66}$ a conclusion of an agreement, ${ }^{67}$ serving of a notice to the companies' commission, ${ }^{68}$ confirmation of the amalgamation or merger transaction, ${ }^{69}$ and a subsequent transfer of assets of the companies in terms of the transaction. ${ }^{70}$

\section{Purposes ancillary to pure headquarter company purposes}

A group of companies sometimes prefers to centralize certain functions within the group. Thus, a group may have a reason, other than a holding reason, to set up a company outside its home country. The reason may be, for a distribution group, a central distribution point for the group either due to the close proximity of the host country to the contiguous target countries, or some other reason.

At times, the headquarter company's functions are undertaken as ancillary to the business activities of an entity that was not set up as a headquarter company. Conversely, an entity may be set up as a headquarter company to perform both headquarter-company functions and functions that are not akin to a headquarter company. Generally, headquarter-company functions are often combined with intermediary holding company. In intermediary holdingcompany's functions are mainly to provide the group of companies with structural flexibility as well as to facilitate acquisitions, management and disposals of investments. ${ }^{71}$

In its purest form, a headquarter company does not own intangibles, make investments or carry on any of the business activities of the group companies. According to Olivier and Honiball, pure headquarter companies are

"generally responsible for any or all of the services which are auxiliary to the multinational group's main business or operational activities on a centralized basis. Examples of such services include accounting, legal, computer, marketing and scientific support services."

The functions of a headquarter company could be combined with the activities of other companies in order to comply with certain regulatory provisions. For example, utilizing a headquarter company located in the European Union to perform various active business activities is generally to

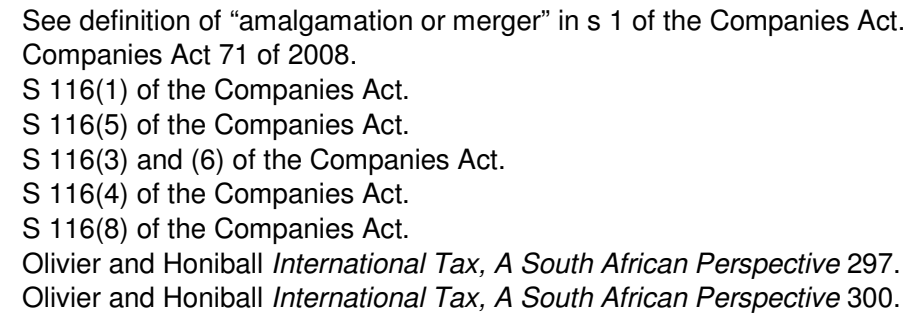


ensure that the headquarter company complies with the anti-avoidance provisions contained in the European Community Merger Directive, ${ }^{73}$ which requires that a holding company should have a bona fide commercial substance in the country in which it is located. ${ }^{74}$

In recent years, company groups have preferred to share employees. According to this arrangement, a company would be set up within a group in a jurisdiction where some or most of the group companies are located. This company would employ people of different expertise. These would generally be people whose skills are required by the group companies on a regular, but not on a full-time ${ }^{75}$ basis (therefore this excludes operational personnel). These members of staff would be deployed to each company as and when needed.

Where such an employee-sharing arrangement is already in place, certain management of the company, which might include the group's operational management, may also be employed by the employment company. Such operational management staff do not necessarily have to be deployed to any group company. The management may perform headquarter functions, thus rendering the company a headquarter company in that jurisdiction. This combination only works in certain restrictive circumstances. ${ }^{16}$

\section{$4 \quad$ CONCLUSION}

The reasons for the formation of a headquarter company are closely linked to the functions of the headquarter company. The group identifies what services it needs and the reasons why it needs such services. In some instances such services cannot be performed by a third party to the group. Where such services can be performed by a group member and fall within the functions of a headquarter company, the reason for the establishment of a headquarter company would have arisen. Thus, the reason for the formation of a headquarter company is focused on exactly what the group aims to achieve with the entity.

For South African purposes, the availability of robust legal protection of property in the form of both property law and constitutional protection provides sufficient security against property violation and poise South Africa as a low risk country to host a headquarter company. The low currency-risk rating also adds to the viability of South Africa as a financially stable country to locate a headquarter company. Furthermore, investors are afforded the ability to list the headquarter company in South Africa in two forms as well as a myriad of finance-backup provisions to serve as collateral against group

\footnotetext{
European Community Merger Directive of 23 July 1990 (90/434/EEC).

Olivier and Honiball International Tax, A South African Perspective 300.

75 "Full-time" is used here in a loose and general sense: tax practitioners disagree as to whether it implies a permanent employment, eight-hour working days, etc.

76 According to Olivier and Honiball International Tax. A South African Perspective 300 "[i]t may not always be possible, however, to combine investment holding activities with other types of business activities due to the restrictive laws of the particular holding company regime. For example, to receive the preferential tax benefits of the Luxembourg 1929 holding company, the company's activities must be restricted to investment holding, acquisition or sale."
} 
assets. The presence of company-reorganization provisions provided by the company laws and specifically relaxed exchange-control rules further provide an ideal infrastructure to set up a headquarter company.

The real reasons why such companies are set up are economic in nature. The prevalence of such reasons in company groups results in the popularity of headquarter companies in large multinational groups. Choosing a jurisdiction is guided by such business and economic reasons. This, however, does not mean that investors should be (or are) oblivious of the tax advantages and disadvantages of establishing the headquarter company in a particular jurisdiction. ${ }^{77}$ Tax reasons are important to the determination of where to set up a headquarter company. ${ }^{78}$ However, the key determinants provide a primary basis of the choice of location.

7 See Eynatten "European Holding Company Tax Regimes: A Comparative Study" 2007 47(12) European Taxation 562-570.

$78 \mathrm{Eg}$, where two jurisdictions grant a similar corporate environment, the investor would not be expected to choose a tax-adverse jurisdiction to preserve the essence of the headquarter company. 